\title{
Retrieval of Trichostrongylus colubriformis infective larvae from grass contaminated in winter and in spring
}

\author{
Recuperação de larvas infectantes de Trichostrongylus colubriformis em gramíneas \\ contaminadas no inverno e na primavera \\ Raquel Abdallah da Rocha ${ }^{1 *}$; Patrizia Ana Bricarello ${ }^{2}$; Gilberto Pedroso da Rocha ${ }^{3}$; \\ Alessandro Francisco Talamini do Amarante ${ }^{4}$

\begin{abstract}
${ }^{1}$ Departamento de Zootecnia, Universidade de Ponta Grossa - UEPG, Ponta Grossa, PR, Brasil
${ }^{2}$ Departamento de Zootecnia e Desenvolvimento Rural, Centro de Ciências Agrárias, Universidade Federal Santa Catarina - UFSC, Florianópolis, SC, Brasil

${ }^{3}$ Departamento de Produçáo Animal, Faculdade de Medicina Veterinária e Zootecnia, Universidade Estadual Paulista - UNESP, Botucatu, SP, Brasil

${ }^{4}$ Departamento de Parasitologia, Instituto de Biociências, Universidade Estadual Paulista - UNESP, Botucatu, SP, Brasil
\end{abstract}

Received May 9, 2014

Accepted September 3, 2014

\begin{abstract}
The survival of infective larvae (L3) of Trichostrongylus colubriformis was evaluated on Brachiaria, Coast-cross and Aruana forage grasses. Feces of sheep parasitized exclusively by T. colubriformis were deposited in winter and spring on experimental plots whose grasses were cut at two heights: $5 \mathrm{~cm}$ and $30 \mathrm{~cm}$. One, two, four, eight, 12 and 16 weeks after depositing the feces, fecal and forage samples were collected for the retrieval and quantification of L3. Retrieval of L3 from feces and forage was negligible in winter due to the dry weather, although a few larvae were retrieved in the last larval collections. However, L3 retrieval from fecal samples was greater in spring, especially two weeks after feces were deposited on $30 \mathrm{~cm}$ high grasses. At this time, the L3 retrieval rate from the three forage grasses differed significantly $(\mathrm{P}<0.05)$, with Aruana grass showing the highest average L3 retrieval rate, followed by Coast-cross and Brachiaria. In conclusion, the winter drought proved very unfavorable for the presence of L3 in the environment, and the microclimate of Aruana pastureland was generally the most favorable for the retrieval of infective larvae.
\end{abstract}

Keywords: Sheep, nematodes, epidemiology, Brachiaria decumbens, Panicum maximum, Cynodon dactylon.

\section{Resumo}

A sobrevivência de larvas infectantes (L3) de Trichostrongylus colubriformis foi avaliada em pastagem de Braquiária, Coast-cross e Aruana. Fezes de ovinos parasitados exclusivamente por T. colubriformis foram depositadas no inverno e na primavera em parcelas experimentais com duas alturas de corte da forragem, $5 \mathrm{~cm}$ e $30 \mathrm{~cm}$. Uma, duas, quatro, oito, 12 e 16 semanas após o depósito, amostras de fezes e de forragem foram coletadas para a recuperação e quantificação de L3. Devido à seca no inverno, a recuperação de L3 das fezes e da forragem foi ínfima, embora tenha havido recuperação de algumas larvas nas últimas coletas. Por outro lado, na primavera houve maior recuperaçáo de L3 das amostras, especialmente duas semanas após a deposiçáo das fezes em meio às pastagens com $30 \mathrm{~cm}$ de altura. Nesse momento, houve diferença significativa $(\mathrm{P}<0,05)$ entre as três forrageiras, com maior média de L3 no capim Aruana, seguido de Coast-cross e Braquiária. Em conclusão, a seca registrada no período de inverno se mostrou bastante desfavorável à presença de L3 no ambiente e, de forma geral, o microclima da pastagem de Aruana foi o que mais favoreceu a recuperação de larvas infectantes.

Palavras-chave: Ovino, nematoides, epidemiologia, Brachiaria decumbens, Panicum maximum, Cynodon dactylon.

*Corresponding author: Raquel Abdallah da Rocha, Departamento de 


\section{Introduction}

Gastrointestinal nematode infections are the main cause of yield losses in the sheep industry in Brazil and in other countries. Parasitism is controlled mainly with anthelmintic drugs, but the persistence of their residues in animal products and the development of the parasites' resistance to various chemical groups have led to the need to adopt other control strategies.

Several control alternatives have been searched, including studies on the population dynamics and location of infective larvae (L3) in different forage grasses commonly used in sheep farming (NIEZEN et al., 1998a, b; ROCHA et al., 2008, 2012).

Pasture management strategies aimed at reducing contamination and the ingestion of L3 by animals are essential to assist in the control of gastrointestinal nematodes (NIEZEN et al., 1998b). Environmental conditions are important not only for the development and survival of free-living stages but also for the migration of L3 to forage grasses. The morphological differences in forage species also influence the development and survival of eggs and larvae in the pasture, due to the different microclimates provided by plants.

Several grass species can be used as forage for sheep, including Brachiaria decumbens cv. Australian, Cynodon dactylon cv. Coastcross and Panicum maximum cv. Aruana, whose growth rates differ. Brachiaria, which has a decumbent growth habit, is a very common grass in Brazil, albeit of relatively low nutritional value. However, Brachiaria produces few stems and its leaves remain green for long periods, which results in lower reductions in nutritional value over time, thus making it suitable to balance the seasonality of forage production (EUCLIDES et al., 2007). Grazing deferment, which consists of reserving areas for grazing in late summer, is a seasonal strategy to enable excess forage produced in late summer to be used during the dry season (TEIXEIRA et al., 2011). The total dry matter produced by Brachiaria grass is approximately 4,305 kg/ha (TEIXEIRA et al., 2011).

Coast-cross has a stoloniferous growth habit. Its production of dry matter varies according to the type of soil and fertilizer, ranging from $3,613 \mathrm{~kg} /$ ha on unfertilized pastures to $6,134 \mathrm{~kg} / \mathrm{ha}$ on pastures treated with replacement fertilizer (FERRARI et al., 1993).

Aruana, with its caespitose growth habit, offers high nutritional value, presenting high productivity, good tolerance to low grazing, as well as an open and upright leaf architecture, which favors greater incidence of solar radiation and increased ventilation within the pasture. However, Aruana grass has high requirements in terms of soil fertility (CECATO et al., 2000). This grass has short internodes and small leaves, thus producing lower volumes of total dry matter (about 6 tons/ha) than other cultivars of the Panicum maximum species (CECATO et al., 2000).

This study involved an evaluation of the retrieval of infective larvae of Trichostrongylus colubriformis from three forage species: $B$. decumbens cv. Australian, C. dactylon cv. Coast-cross and P. maximum cv. Aruana. The influence of the height of the forage grasses $(5$ and $30 \mathrm{~cm}$ ) at the time of contamination and of the season (spring and winter) on larval retrieval was also evaluated.

\section{Materials and Methods}

The fieldwork involved in the experiment was carried out in the area of Sheep Production of the Department of Animal Production at the Faculty of Veterinary Medicine and Animal Science, and the lab work at the Department of Parasitology of the Institute of Biosciences, both of the São Paulo State University - UNESP at Botucatu (22 $50^{\prime}$ S; 4824'W). The meteorological data were obtained from the Area of Environmental Sciences of the Department of Natural Resources, Faculty of Agricultural Sciences of UNESP at Botucatu.

Infective larvae of T. colubriformis were obtained and kept as described by Rocha et al. (2007).

\section{Experimental modules}

The experimental modules consisted of six $32.4 \mathrm{~m}^{2}$ plots planted with $B$. decumbens cv. Australian, $C$. dactylon cv. Coast-cross or $P$. maximum cv. Aruana, two plots per grass species.

Each plot was divided into thirty-six $30 \times 30 \mathrm{~cm}$ subdivisions, using nylon thread and wooden stakes. To prevent the three species from invading each others' areas, the spaces between plots were weeded regularly.

Larval retrieval rates were assessed under the effect of two forage cutting heights (low $=5 \mathrm{~cm}$ and high $=30 \mathrm{~cm}$ ). Cutting was done immediately prior to depositing the feces, using suitable pruning shears to prevent sectioned parts from falling to the ground.

\section{Fecal deposits}

Two fecal deposits were made: one in winter (05 August 2004) and the other in spring (24 November 2004). The feces were deposited on the experimental plots between 12:00 noon and 1:00 p.m. The average temperature on the days when fecal deposits were made was $18.2^{\circ} \mathrm{C}$ in winter and $23.4^{\circ} \mathrm{C}$ in spring Fecal samples were collected using fecal collection bags attached to sheep infected with T. colubriformis (details in Rocha et al. (2007)).

On the day feces were deposited, five counts of eggs per gram of feces (EPG) were made to estimate the total number of T. colubriformis eggs in the samples. A total of 221 samples were prepared. The samples deposited in spring contained 20 grams of feces (average $280 \mathrm{EPG}$ ), while those deposited in winter contained 15 grams of feces (average $1500 \mathrm{EPG}$ ).

\section{Retrieval of $L 3$ from grass and fecal samples}

The fecal and grass samples were collected one, two, four, eight, 12 and 16 weeks after the feces were deposited on the experimental plots. Each week, samples were collected, per forage species and per height, from the six plots. All sample collections were carried out between 6:30 and 7:30 a.m. The retrieval of L3 from the grass and fecal samples is described in detail in Rocha et al. (2008).

The height of the grass in each experimental plot was measured immediately before cutting it. The grass was cut with pruning shears, close to the ground, inside a ring with a radius of $10 \mathrm{~cm}$. The size 
of the ring was determined based on the fact that approximately $90 \%$ of the larvae did not migrate laterally more than $10 \mathrm{~cm}$ away from the feces (SKINNER \& TODD, 1980). Grass samples were stored separately in buckets. They were kept immersed in $4 \mathrm{~L}$ of water for four hours. After that, each herbage sample was transferred to another bucket containing $4 \mathrm{~L}$ of water, remaining immersed for further three hours (NIEZEN et al., 1998a; ROCHA et al., 2012). After the period of immersion, the grass samples were removed, placed in paper bags and oven-dried to calculate the weight of dry matter. The water in the buckets was allowed to rest for 24 hours, after which the supernatant was removed and the sediment was transferred to a sedimentation jar. After an additional 24 hours of sedimentation, the supernatant was discarded and the sediment was transferred to graduated conical tube with caps. The tubes were stored in a refrigerator $\left(4^{\circ} \mathrm{C}\right)$ until reading was performed, when the supernatant was again discarded and $1.0 \mathrm{ml}$ of sediment was examined to quantify $T$. colubriformis L3. The results were expressed as the mean number of L3. In addition, the mean concentration of L3 on the grass, i.e., the mean number of L3 per kilogram of dry matter (L3/kg DM), was estimated.

The feces that remained on the plots were collected and stored in labeled plastic bags until they were processed in the laboratory. The larvae were separated from the feces, as described previously by Rocha et al. (2008).

Based on the number of infective larvae collected from feces deposited on the plots relative to the number of infective larvae produced in the fecal cultures kept in the laboratory (control), the larval retrieval rate from the environment was calculated using the following formula:
Retrieval rate $=100 *$ (mean number of L3 retrieved from feces deposited in the environment / mean number of L3 in the cultures of the control group).

\section{Statistical analysis}

The data of L3 from feces, L3 from pasture, L3/kg DM pasture and height of pasture were subjected to one-way analysis of variance and means were compared by Tukey's test with a 5\% level of significance, using Minitab software (version 11, 1996). L3 from feces, L3 from pasture and L3/kg DM pasture data were transformed to $\log _{10}(x+1)$ prior to analysis. However, the arithmetic means of non-transformed data are presented to clarify the results.

\section{Results}

\section{Winter}

The fecal samples contained an average of 1500 EPG. The average number of larvae collected from the control group cultures was $1740 \mathrm{~L} 3$, which corresponds to a development rate from egg to $\mathrm{L} 3$ of $5.8 \%$.

The average temperature on the day feces were deposited was $18.2^{\circ} \mathrm{C}$. The day was sunny and the relative air humidity was $45 \%$. No major variations in temperature or humidity occurred during the initial 20 days after the deposit. Figure 1 shows the climate data.
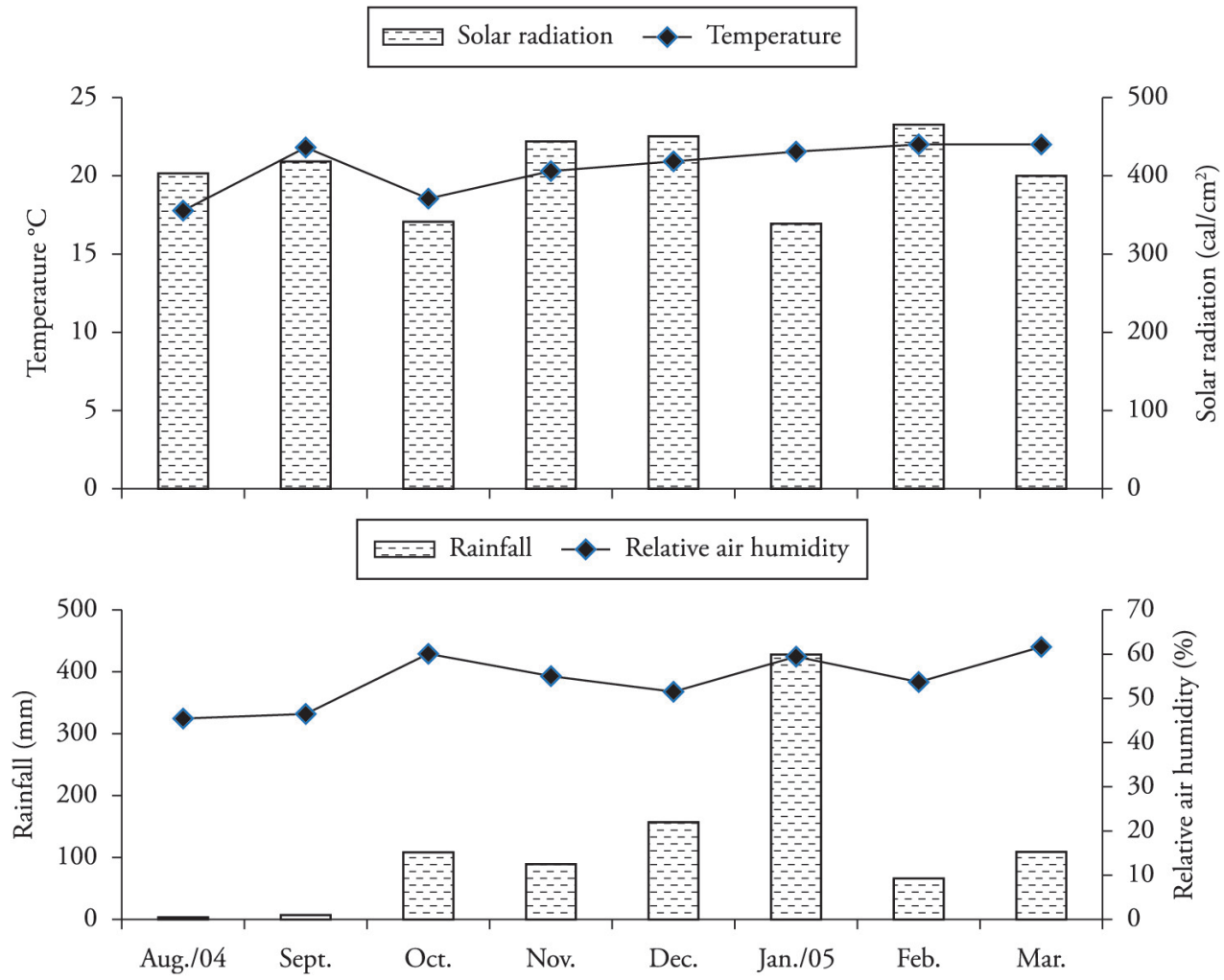

Figure 1. Monthly average temperature $\left({ }^{\circ} \mathrm{C}\right)$, relative air humidity $(\%)$, total rainfall $(\mathrm{mm})$, and solar radiation $\left(\mathrm{cal} / \mathrm{cm}^{2}\right)$ from August 2004 to March 2005 in Botucatu, state of São Paulo, Brazil. 


\section{Low cutting height (Figure 2)}

The development rate from egg to L3 in feces was very low. The highest retrieval rate occurred in week 12 from feces deposited on Aruana grass (0.6\%). The development rate was low $(5.8 \%)$ even in the in vitro cultures.

As a result, the retrieval rate of $\mathrm{L} 3$ from the grasses was almost non-existent after the fecal deposit performed in winter. L3 were retrieved only from Aruana and Coast-cross during week 2 and from Brachiaria and Aruana in week 12. In week 12, the retrieval rate of L3 from Aruana grass was higher than from Coast-cross $(\mathrm{P}<0.05)$. After the deposit of feces on the plots, there was little rainfall until week 8 (6.9 $\mathrm{mm}$ during this period). The average temperature was about $19.9^{\circ} \mathrm{C}$ and the relative humidity $(\mathrm{RH})$ varied from $34 \%$ to $73 \%$. From then on, it rained occasionally until week $12(109 \mathrm{~mm})$. The mean temperature in this period (from week 8 to week 12 ) was $18.3^{\circ} \mathrm{C}$ and the $\mathrm{RH}$ ranged from $39 \%$ to $78 \%$.

The retrieval rate of $\mathrm{L} 3 / \mathrm{kg}$ DM was likewise low during several weeks. Significant retrieval rates were recorded only in week 12 from Aruana grass (740.7 L3/kg DM), which showed a higher average than Brachiaria and Coast-cross (145.1 and 0 L3/kg DM, respectively; $\mathrm{P}<0.05$ ).

The grasses showed similar growth over several weeks. In week 2, Coast-cross presented the lowest height $(9 \mathrm{~cm})$, differing from Aruana $(12.67 \mathrm{~cm} ; \mathrm{P}<0.05)$. However, in week 16, Brachiaria presented the greatest height $(59.17 \mathrm{~cm})$, differing from Aruana and Coast-cross $(41.5 \mathrm{~cm}$ and $39.5 \mathrm{~cm}$, respectively; $\mathrm{P}<0.05)$.
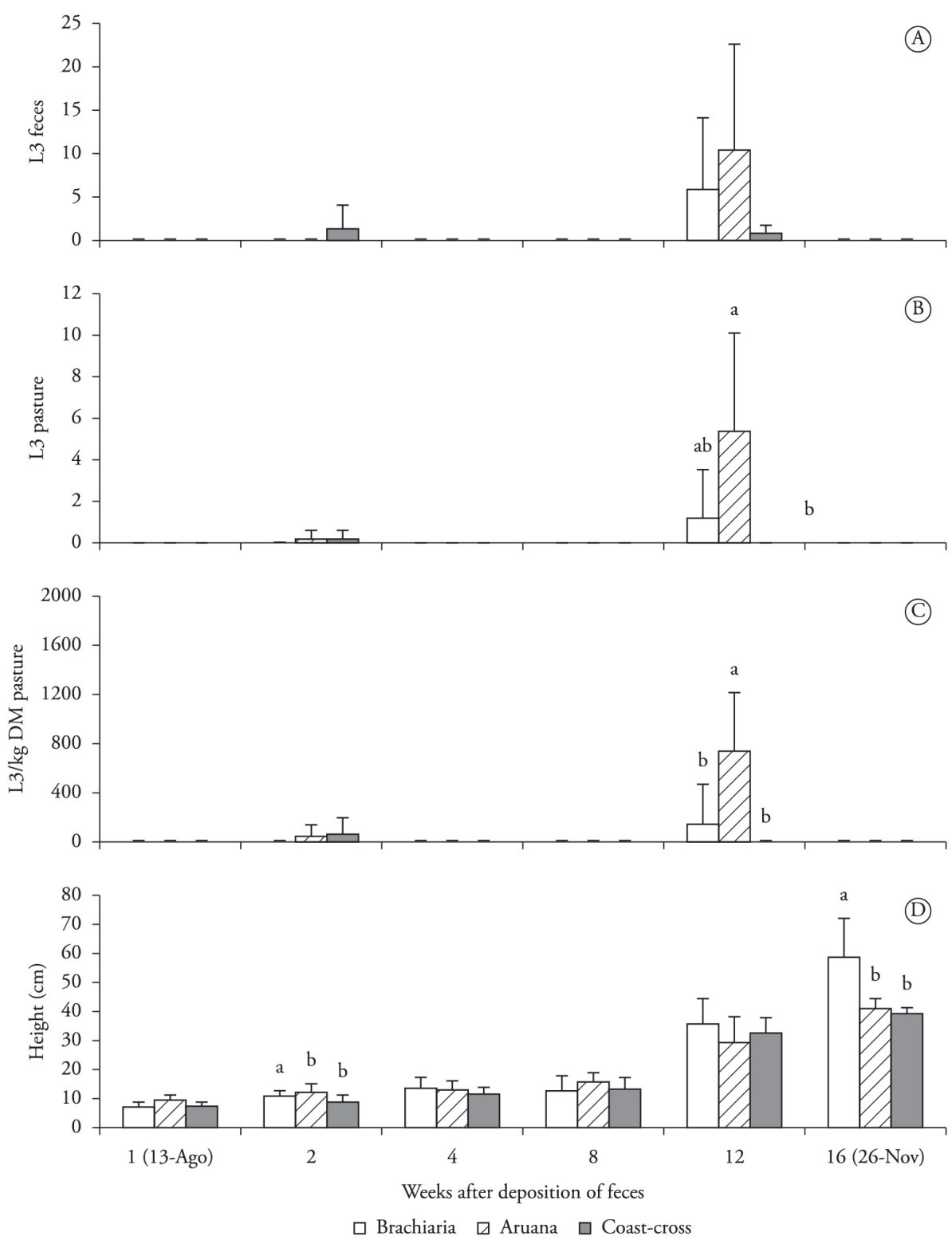

Figure 2. Average number of infective larvae of Trichostrongylus colubriformis in feces (A); pasture (B); and per kilogram of herbage dry matter (L3/kg DM) (C); and average pasture height (D) of Brachiaria, Aruana and Coast-cross during the experiment conducted in Botucatu, state of São Paulo, Brazil. Samples deposited on grasses with an initial height of $5 \mathrm{~cm}$ (on 05 Aug 2004). Bars = standard deviation. Different letters indicate a significant difference $(\mathrm{P}<0.05)$ between means of the week. 
Like grass height, grass weight was also low. Weight differences occurred only in weeks 2 and 16. In those weeks, Brachiaria was heavier (12.61 and $21.59 \mathrm{~g}$, respectively) than Aruana (3.53 and $11.19 \mathrm{~g}$, respectively) and Coast-cross (3.47 g and 11.72, respectively; $\mathrm{P}<0.05)$.

The fecal pellets recovered during the experimental weeks kept their aspect intact without signs of fecal decomposition.

\section{High cutting height (Figure 3)}

The egg to L3 development rate was very low. Maximum development was recorded in week 12 (0.7\%), when fecal samples were deposited on Aruana grass. Similarly to what occurred when the grass cut at a low height, the retrieval rate of L3 from high cut grasses was almost zero after the winter contamination (Figure 3).

Differences in grass height were recorded in week 4 (Aruana: $39.83 \mathrm{~cm}$; Coast-cross: $31.18 \mathrm{~cm} ; \mathrm{P}<0.05)$ and in week 16 (Brachiaria: $78.5 \mathrm{~cm}$; differing from Aruana and Coast-cross, which showed 63.17 and $57.67 \mathrm{~cm}$, respectively; $\mathrm{P}<0.05$ ).

As for grass weight, significant differences were found in weeks 1 and 16. In week 1, the weight of Brachiaria exceeded that of Aruana (21.47 g and 10.24 g, respectively; $\mathrm{P}<0.05)$. In week 16, Brachiaria weighed more (59.13 g) than Aruana and Coast-cross (30.4 g and 29.22 g, respectively; $\mathrm{P}<0.05$ ).

Like the case of low cut grass, no fecal decomposition was observed during the experimental weeks.
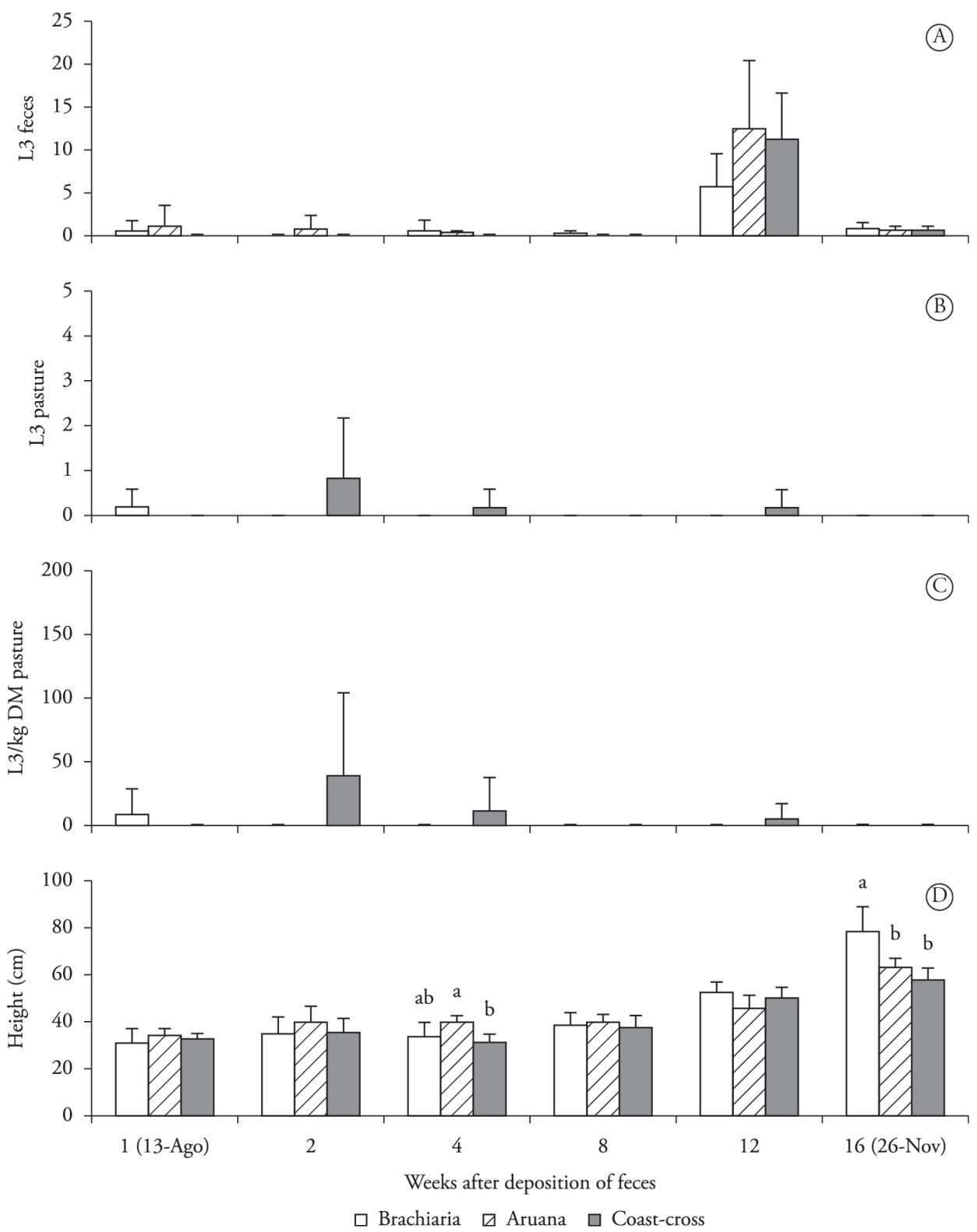

Figure 3. Average number of infective larvae of Trichostrongylus colubriformis in feces (A); pasture (B); and per kilogram of herbage dry matter (L3/kg DM) (C); and average pasture height (D) of Brachiaria, Aruana and Coast-cross during the experiment conducted in Botucatu, state of São Paulo, Brazil. Samples deposited on grasses with an initial height of $30 \mathrm{~cm}$ (on 05 Aug 2004). Bars = standard deviation. Different letters indicate a significant difference $(\mathrm{P}<0.05)$ between means of the week. 


\section{Comparison of low and high forage cutting heights}

The retrieval rate of L3 from feces deposited on the grass in winter presented only the sward height effect on the late samplings, i.e., in weeks 12 and 16. In these weeks, the high cutting height favored a higher retrieval rate of L3 from feces deposited on Coast-cross (weeks 12 and 16) and Aruana (week 16). As for the L3 retrieved from grasses, the only difference was found with Aruana, when, also in a late sample collection in week 12, this forage plant exhibited a higher L3 retrieval rate (absolute number of L3 and number of L3/kg DM) from low cut grass than from high cut grass.

\section{Spring}

The fecal samples showed an average count of 280 EPG. The average number of larvae retrieved from the control group cultures was $1630 \mathrm{~L} 3$, which corresponded to an egg to L3 development rate of $29.1 \%$.

The average temperature on the day feces were deposited on the plots was $23.4^{\circ} \mathrm{C}$. The day was sunny and the relative air humidity was $43 \%$. No major variations in temperature or humidity occurred during the days after the deposit.

\section{Low cutting height (Figure 4)}

The maximum development rate in the fecal samples deposited in Brachiaria was 3.4\% and occurred in week 2. Infective larvae were retrieved from feces on all the experimental plots up to week 4, from Aruana plots up to week 8, and from Brachiaria plots up to week 12 . The number of L3 retrieved from feces in week 2 differed significantly, with a higher average number found on Brachiaria than on Coast-cross (55 and 13.83 L3, respectively; $\mathrm{P}<0.05$ ).

During week 2, larger numbers of infective larvae were retrieved from Aruana than from the other two grass species $(\mathrm{P}<0.05)$.

Large numbers of $\mathrm{L} 3 / \mathrm{kg}$ DM were recorded up to week 8 (December 2004 and January 2005). Aruana grass presented $3804 \mathrm{~L} 3 / \mathrm{kg}$ DM in week $2(\mathrm{P}<0.05)$, exceeding that of Brachiaria (12.5 L3/kg DM) and Coast-cross (197.4 L3/kg DM) $(\mathrm{P}<0.05$ - Figure 4). The latter also differed from Brachiaria $(\mathrm{P}<0.05)$. The average temperature during this period (weeks 1 to 8 ) was $21.4^{\circ} \mathrm{C}$, with average maximum and minimum temperatures of $27.8^{\circ} \mathrm{C}$ and $18.4^{\circ} \mathrm{C}$. Rainfall was $316 \mathrm{~mm}$ and the daily relative air humidity varied from $41 \%$ to $66 \%$.

Starting in week 8 , grass growth began to show significant differences. In weeks 8 and 16, Brachiaria grew considerably taller than Aruana and Coast-cross $(\mathrm{P}<0.05)$. However, in week 12, Brachiaria height differed only from that of Aruana $(\mathrm{P}<0.05)$.

The weight of the grasses differed significantly only in week 16, when Brachiaria weighed $43.86 \mathrm{~g}$ and Aruana weighed $18.53 \mathrm{~g}$ $(\mathrm{P}<0.05)$.

The deposited feces showed progressive decomposition, and during the last harvest, only $10 \%, 10.5 \%$ and $18.5 \%$ of the deposited feces remained, respectively, on Brachiaria, Aruana and Coast-cross.

\section{High cutting height (Figure 5)}

In weeks 1 and 2, the development rate from egg to L3 in feces exceeded 1\%. Larvae were retrieved from fecal samples on all the grasses up to week 4. However, in week 8, larvae were retrieved only from Brachiaria and Aruana. During week 12 no larvae were retried from any of the forage species, and in week 16, larvae were only found on Coast-cross. In general, the highest retrieval rate of L3 was from fecal samples deposited on Brachiaria, albeit without a statistically significant difference $(P>0.05)$ from the other grasses.

The highest retrieval rate of L3 from grass occurred in Aruana and Coast-cross, which showed higher averages than Brachiaria in week $2(\mathrm{P}<0.05)$. In week 4 , the $\mathrm{L} 3$ retrieval rate from Aruana grass was higher than from Brachiaria $(\mathrm{P}<0.05)$.

The largest numbers of L3/kg DM were recorded in week 2 . In week 4, Aruana presented a higher quantity of L3/kg DM than Brachiaria (85.51 and 10.95 L3/kg DM, respectively; $\mathrm{P}<0.05$ ).

The forage grasses showed a similar growth rate until week 4 . In week 8, however, the average heights of the three grasses differed significantly: Brachiaria was the tallest, followed by Aruana and Coast-cross. In weeks 12 and 16, Brachiaria differed only from Coast-cross $(\mathrm{P}<0.05)$.

Coast-cross weighed more in week 2 than Brachiaria and Aruana $(\mathrm{P}<0.05)$. However, in week 12, the weight of Brachiaria exceeded that of Aruana $(\mathrm{P}<0.05)$.

The weight of retrieved feces remained similar up to week 4. In week 8 , the weight of feces retrieved from Aruana grass exceeded that retrieved from Coast-cross $(\mathrm{P}<0.05)$. In week 12 , the weight of feces retrieved from the Coast-cross plots was only $0.74 \mathrm{~g}$, which is lower $(\mathrm{P}<0.05)$ than the average weights retrieved from Brachiaria $(2.89 \mathrm{~g})$ and Aruana $(3.28 \mathrm{~g})$. In the last harvest, only $17.8 \%, 29 \%$ and $7.5 \%$ of the deposited feces remained, respectively, on the Brachiaria, Aruana and Coast-cross grasses.

\section{Comparison of high and low forage cutting heights}

In general, the high cutting height favored a higher retrieval rate of L3 from feces collected from Brachiaria in week 1 and from Coast-cross in week 2, as well as a higher retrieval rate of L3 from the forage species (absolute number of L3) in the second collection from Coast-cross $(\mathrm{P}<0.05)$. However, in week 2, Aruana (number of L3/kg DM) and in week 4, Brachiaria (absolute number of L3 and number of $\mathrm{L} 3 / \mathrm{kg}$ DM) presented higher retrieval rates of L3 from low cut than from high cut grasses $(\mathrm{P}<0.05)$.

\section{Discussion}

\section{Winter}

In general, the retrieval rate of larvae from both feces and forage grasses was very low and during several weeks no larvae were recovered. These results may be related to the low percentage of development observed in the laboratory cultures (5.8\%). Moreover, there was a severe drought in the months of August and September, which also possibly contributed to the low larval retrieval rate. 

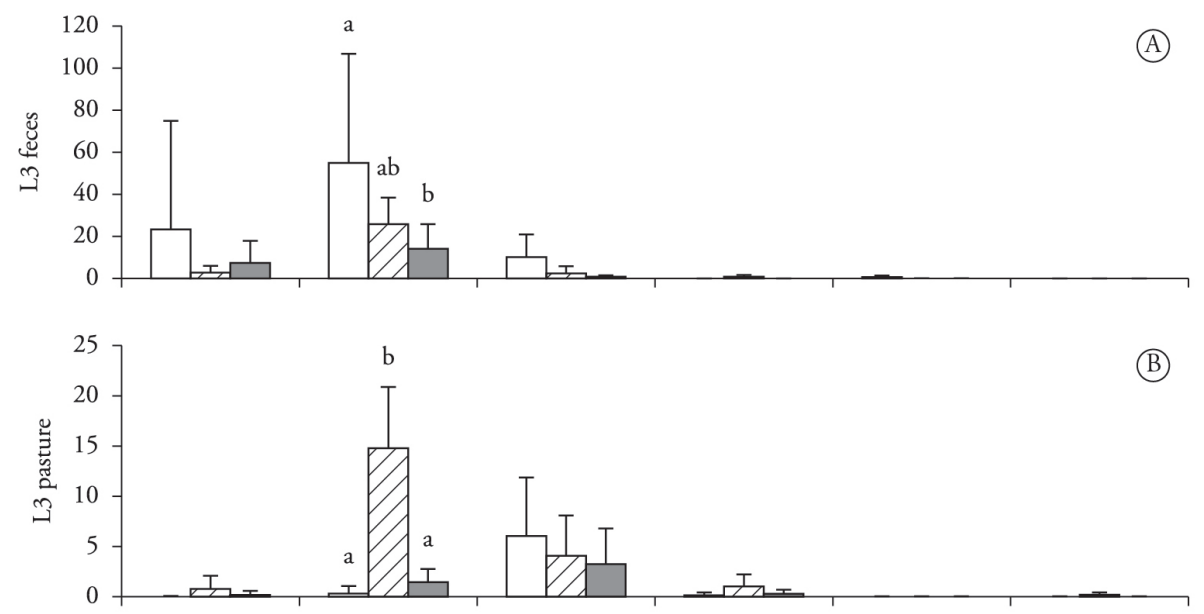

b
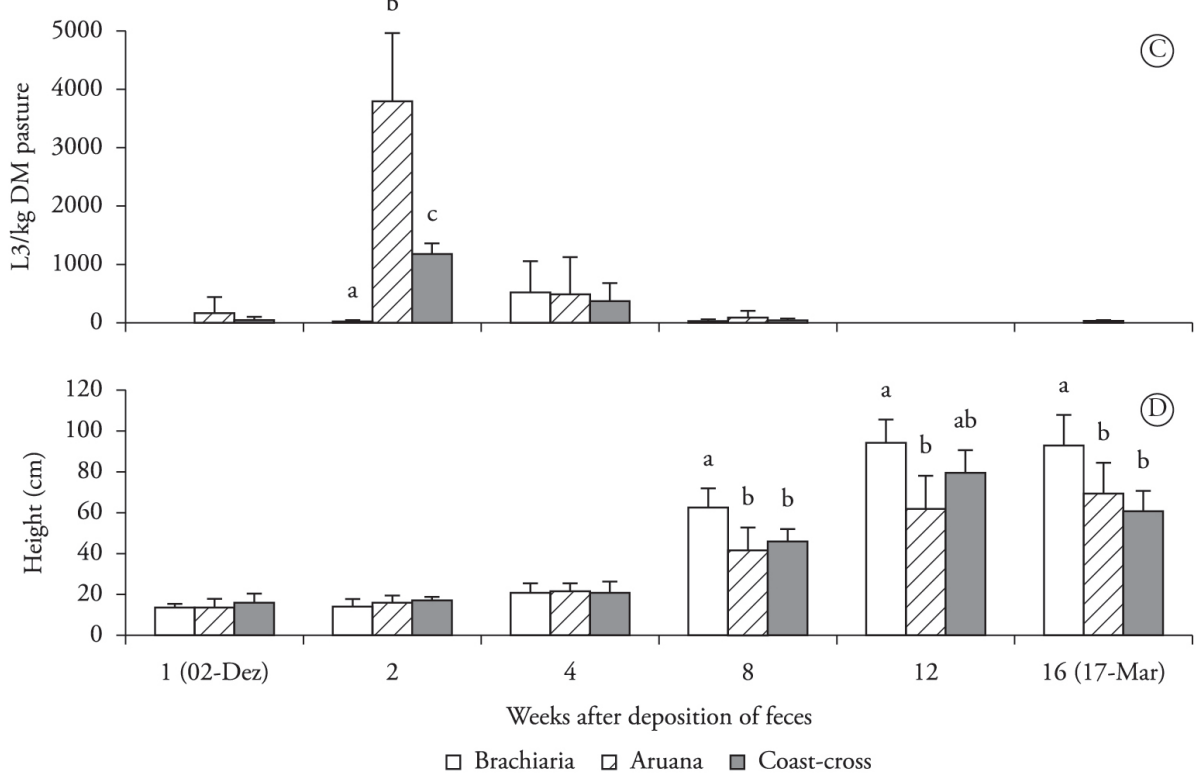

Figure 4. Average number of infective larvae of Trichostrongylus colubriformis in feces (A); pasture (B); and per kilogram of herbage dry matter (L3/kg DM) (C); and average pasture height (D) of Brachiaria, Aruana and Coast-cross during the experiment conducted in Botucatu, state of São Paulo, Brazil. Samples deposited on grasses with an initial height of $5 \mathrm{~cm}$ (on 24 Nov 2004). Bars = standard deviation. Different letters indicate a significant difference $(\mathrm{P}<0.05)$ between means of the week.

Cattle dung deposited during dry months remains as a source of infection, since the conditions within the fecal mass are favorable for the evolution and survival of free-living stages of Trichostrongylus axei. The surface of fecal matter deposited in the environment during the dry season hardens very quickly, inhibiting the migration of larvae to pasture grasses. However, this rapid hardening prevents moisture loss from inside the mass, providing favorable conditions for the evolution and survival of the free-living stages of the parasite (CATTO, 1982). Almeida et al. (2005) also found that low rainfall associated with warm temperatures may determine the long-lasting survival of L3 in sheep fecal pellets.

Rocha et al. (2007), who evaluated the vertical migration of T. colubriformis L3 in different strata of Brachiaria and Aruana grasses, also retrieved no larvae from any stratum of these grasses in summer or winter, attributing it to the influence of climatic conditions.
In the present study, the drought probably had an adverse effect on larval development in the feces deposited in August (winter). However, it did not affect larval survival, since L3 were collected from the pasture in October, when it rained occasionally, demonstrating the importance of moisture on larval development. It is possible that the eggs developed to the embryonic stage and then became quiescent due to environmental conditions that were unfavorable for their development. When the rains returned (after week 8), the embryonic eggs began to develop again, reaching L3. The embryonic eggs and L3 of T. colubriformis are generally more resistant to high and low temperatures than non-embryonic eggs and first and second stage larvae (ANDERSEN et al., 1966; ANDERSEN \& LEVINE, 1968). These findings coincide with those obtained by Ndamukong and Ngone (1996), who found a higher development rate up to L3 in feces deposited during the rainy season, while development in the dry season was minimal. 

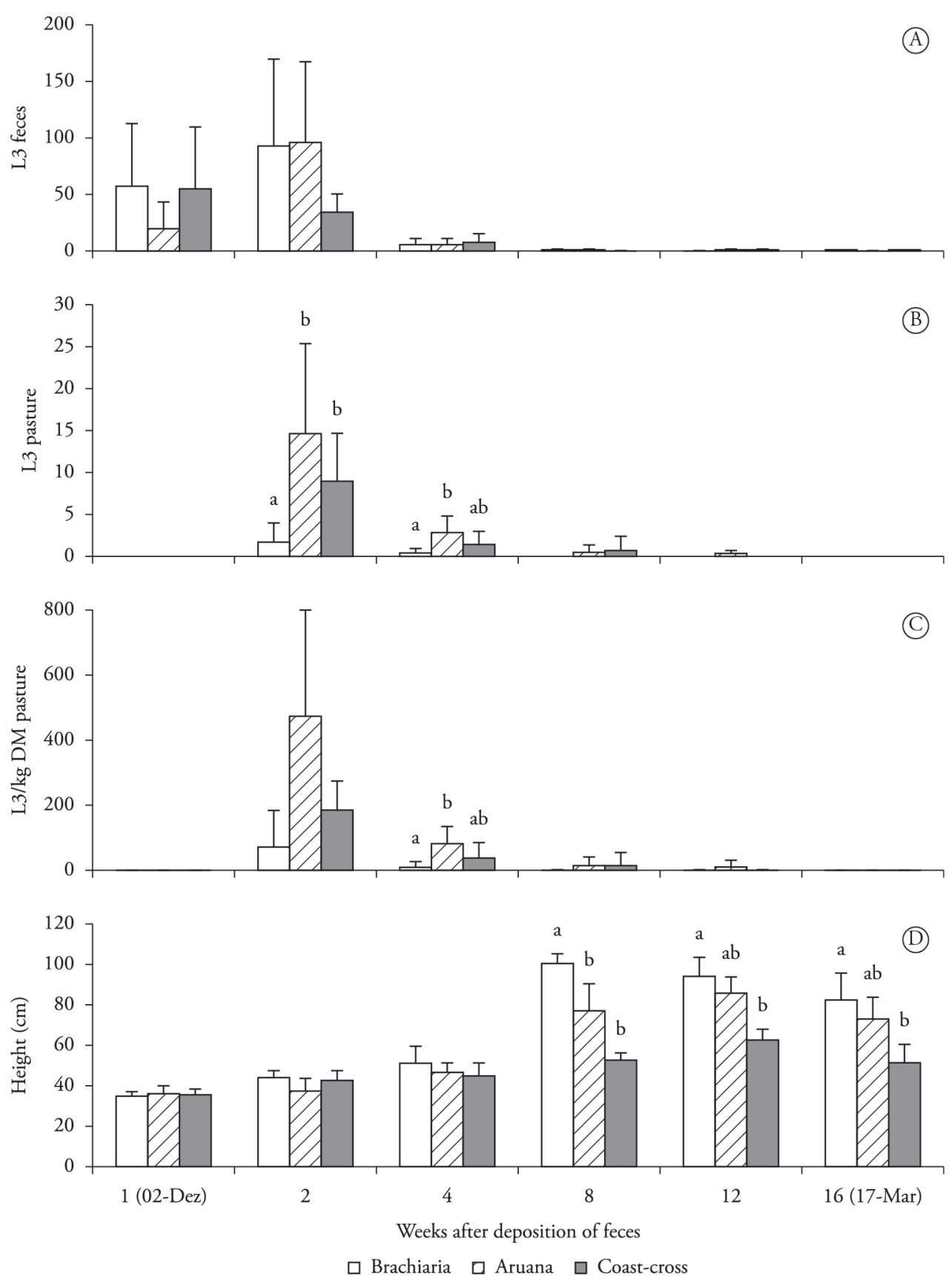

Figure 5. Average number of infective larvae of Trichostrongylus colubriformis in feces (A); pasture (B); and per kilogram of herbage dry matter (L3/kg DM) (C); and average pasture height (D) of Brachiaria, Aruana and Coast-cross during the experiment conducted in Botucatu, state of São Paulo, Brazil. Samples deposited on grasses with an initial height of $30 \mathrm{~cm}$ (on 24 Nov 2004). Bars = standard deviation. Different letters indicate significant difference $(\mathrm{P}<0.05)$ between means of the week.

Silva et al. (2008) found that when pasture was contaminated in winter, most of the L3 remained inside the feces during the dry season, while rainfall favors larval migration to pasture grasses (CATTO, 1982; SILVA et al., 2008).

Forage grass species may influence the migration of L3 of gastrointestinal nematodes (MARLEY et al., 2006a, b; ROCHA et al. 2007). In general, Aruana grass produced higher concentrations of L3 (in feces and pasture, and L3/kg DM) than the other grass species. The pilosity of forage species was not measured. However,
Brachiaria was markedly more pilose than the other species. On the other hand, Aruana grass blades were very smooth, which may explain the higher retrieval rate of L3 from this forage species after occasional rains, because the larvae do not have to overcome any physical barrier. However, Oliveira et al. (2009) found no influence of trichomes on migration of Haemonchus contortus L3 on the forages. In winter, the climatic conditions played a more prominent role in controlling the development of gastrointestinal nematodes than the different forage species. 


\section{Spring}

Overall, the highest retrieval rates of L3 from faces occurred when the samples were deposited on tall forage grass $(30 \mathrm{~cm})$. In an experiment conducted with the same tropical forage plants, Carneiro and Amarante (2008) also retrieved larger numbers of L3 of $H$. contortus from feces deposited in tall grass. Similar findings were reported in a study using the same grasses, when contamination by $T$. colubriformis was performed in summer (ROCHA et al., 2008) and autumn (ROCHA et al., 2012). This fact demonstrates that the greater pasture forage mass probably provided a more favorable microclimate for the development and survival of larvae in grass.

Larvae were retrieved from both forage grasses and feces up to week 16. Development rates exceeding 1\% were recorded in spring. The development rate was also high, but the larvae remained for a shorter time in the environment, probably due to the higher mortality rate resulting from higher temperatures. These findings are similar to those reported by Amarante et al. (1996), who studied the contamination of paddocks grazed continuously by cattle and sheep in the same region as that of this study, and found larger numbers of L3 of Trichostrongylus spp. in the months of May, September and October.

Unlike the retrieval of larvae from fecal samples, the number of L3 retrieved from the experimental plots was not influenced by plant height, as indicated by the fact that a similar number were retrieved from low and high cut grass. However, Carneiro and Amarante (2008) retrieved larger numbers of L3 of $H$. contortus from forage plants when fecal samples were deposited on tall grass $(30 \mathrm{~cm})$. The difference between the results of this work and those of Carneiro and Amarante (2008) may be due to the fact that $H$. contortus larvae are more sensitive to desiccation than T. colubriformis larvae. Embryonic eggs of T. colubriformis are more resistant to high and low temperatures than non-embryonic eggs (ANDERSEN et al., 1966; ANDERSEN \& LEVINE, 1968). Like embryonic eggs, L3 are highly resistant to desiccation (ANDERSEN \& LEVINE, 1968). Silva et al. (2008) found larger numbers of $\mathrm{L} 3$ of $H$. contortus on the upper portions of $B$. decumbens in September (spring) and December (summer).

The number of L3 retrieved from pastures in a study by Rocha et al. (2012) was also not influenced by plant height, except in Brachiaria and Aruana grasses, in which the largest number of L3 were retrieved from high cut grasses in week 4 after contamination of the grass species with feces containing T. colubriformis eggs.

Although a similar number of L3 were retrieved from the three forage grasses cut at the two heights, the concentrations of L3 differed, since higher concentrations of larvae (L3/ kg DM) were collected from low cut grasses than high cut ones. From the epidemiological standpoint, if the concentration of L3 in tall grass is diluted, the animals will also ingest fewer larvae, thus reducing their exposure to these parasites. Moreover, grazing on forage plants with greater availability of DM can increase the nutritional intake of livestock, with a positive effect on their productivity. On average, Bassetto et al. (2009) found 7.2 and 3.1 L3/kg DM of T. colubriformis in paddocks grazed, respectively, by susceptible and resistant sheep. Their findings are similar to those of the present study.

In spring, a total of $5693.91 \mathrm{~L} 3 / \mathrm{kg}$ DM (sum of all the weeks) was recorded in low cut grasses and of $912.95 \mathrm{~L} 3 / \mathrm{kg}$ DM in tall grasses. Carneiro et al. (1990) also found increased contamination in October, April and May. Similar results were observed by Almeida et al. (2005) in Baixada Fluminense, state of Rio de Janeiro, Brazil. These authors studied the development, survival and distribution of Trichostrongylidae in pastures contaminated with sheep, goat and cattle dung in the dry season (May to October). They reported that L3 survived for 15 weeks on pasture contaminated with fecal samples from sheep and goats, while the retrieval of L3 from cattle dung continued for up to 21 weeks after the pastures were contaminated. The highest retrieval rate of $\mathrm{L} 3$ occurred in the third week after contamination (ALMEIDA et al., 2005).

In the present study, infective larvae were still retrieved from pastures three months after fecal deposits were made, indicating that these parasites survive for a reasonable period of time in the pasture. These results differed from those obtained by Ndamukong and Ngone (1996) who suggested that pastureland in Africa can be considered safe three months after contamination. In the location of their experiment, the dry season last from November to March. The total rainfall recorded during this period was less than $50 \mathrm{~mm}$. In Nigeria, sheep and goat pastures can be considered free from contamination during the dry season (CHIEJINA et al., 1989). In the Brazilian semi-arid northeast, the transmission of parasites is likewise practically zero during the dry season (CHARLES, 1989). In regions of low rainfall during certain seasons of the year, such as Brazil's southeast and central-west, rotational grazing systems cannot be employed efficiently as a tool in the control of nematode parasites.

In this study, the highest $T$. colubriformis L3 retrieval rate was from Aruana grass in the second week after contamination of the experimental plots. Thereafter, retrieval rate of L3 from all the forage grasses declined. This fact can be attributed to the high temperatures recorded during this period, allied to the low relative humidity. In other words, the climatic conditions led to rapid larval development and a brief survival time of L3.

It should also be noted that the forage species under study here have different soil fertility requirements. However, the experimental plots were fertilized according to the routine practice at the site of the experiment, where the predominant species is $B$. decumbens. This may explain the low production of dry matter of Aruana grass, which resulted in higher concentrations of L3/ kg DM. Aruana grass usually produces little dry matter when it is insufficiently fertilized, since it is the most demanding of $P$. maximum cultivars (CECATO et al., 2000).

In general, higher concentrations of L3 were found in Aruana grass than in the other forage species. Carneiro and Amarante (2008) also reported higher retrieval rates of L3 of $H$. contortus in Aruana. In general, Brachiaria was found to be the densest forage, followed by Coast-cross. The effect of this higher density was to dilute the L3, causing them to present the lowest concentrations of $\mathrm{L} 3 / \mathrm{kg}$ DM. 


\section{References}

Almeida LR, Castro AA, Silva FJ, Fonseca AH. Desenvolvimento, sobrevivência e distribuição de nematóides gastrintestinais de ruminantes, na estação seca da Baixada Fluminense, RJ. Rev Bras Parasitol Vet 2005; 14(3): 89-94. PMid:16229751.

Amarante AFT, Padovani CR, Barbosa MA. Contaminaçáo da pastagem por larvas infectantes de nematódeos gastrintestinais parasitas de bovinos e ovinos em Botucatu-SP. Rev Bras Parasitol Vet 1996; 5(2): 65-73.

Andersen FL, Levine ND. Effect of desiccation on survival of the freeliving stages of Trichostrongylus colubriformis. J Parasitol 1968; 54(1): 117-128. http://dx.doi.org/10.2307/3276885. PMid:5641035

Andersen FL, Wang GT, Levine ND. Effect of temperature on survival of the free-living stages of Trichostrongylus colubriformis. J Parasitol 1966; 52(4): 713-721. http://dx.doi.org/10.2307/3276439. PMid:5969113

Bassetto CC, Silva BF, Fernandes S, Amarante AF. Contaminacao da pastagem com larvas infectantes de nematoides gastrintestinais apos o pastejo de ovelhas resistentes ou susceptiveis a verminose. Rev Bras Parasitol Vet 2009; 18(4): 63-68. http://dx.doi.org/10.4322/ rbpv.01804012. PMid:20040212

Carneiro JR, Linhares GC, Calil F, Rodrigues N, Campos DMB. Dinâmica das parasitoses gastrintestinais de bovinos em pastagens de braquiária e andropogon. Arq Bras Med Vet Zootec 1990; 42(5): 371-378.

Carneiro RD, Amarante AFT. Seasonal effect of three pasture plants species on the free-living stages of Haemonchus contortus. Arq Bras Med Vet Zootec 2008; 60(4): 864-872. http://dx.doi.org/10.1590/S010209352008000400014 .

Catto JB. Desenvolvimento e sobrevivência de larvas infectantes de nematódeos gastrintestinais de bovinos, durante a estação seca, no Pantanal Mato-Grossense. Pesquisa Agropecu Bras 1982; 17(6): 923-927.

Cecato U, Machado AO, Martins EN, Pereira LAF, Barbosa MAAF, Santos GT. Avaliação da produção e de algumas características da rebrota de cultivares e acessos de Panicum maximum Jacq. sob duas alturas de corte. R Bras Zootec 2000; 29(3): 660-668. http://dx.doi.org/10.1590/ S1516-35982000000300004.

Charles TP. Seasonal prevalence of gastrointestinal nematodes of goats in Pernambuco State, Brazil. Vet Parasitol 1989; 30(4): 335-343. http:// dx.doi.org/10.1016/0304-4017(89)90103-9. PMid:2728324

Chiejina SN, Fakae BB, Eze PI. Development and survival of free-living stages of gastrointestinal nematodes of sheep and goats on pasture in the Nigerian derived savanna. Vet Res Commun 1989; 13(2): 103-112. http:// dx.doi.org/10.1007/BF00346720. PMid:2773307

Euclides VPB, Macedo MCM, Zimmer AH, Medeiros RN, Oliveira MP. Características do pasto de capim-tanzânia adubado com nitrogênio no final do verão. Pesquisa Agropecu Bras 2007; 42(8): 1189-1198. http:// dx.doi.org/10.1590/S0100-204X2007000800017.

Ferrari E Jr, Rodrigues LRA, Reis RA, Coan O, Schammass EA. Avaliação do capim coast cross para produção de feno em diferentes idades e níveis de adubação de reposição. B Industr Anim 1993; 50(2): 137-145.

Marley CL, Fraser MD, Roberts JE, Fychan R, Jones R. Effects of legume forages on ovine gastrointestinal parasite development, migration and survival. Vet Parasitol 2006a; 138(3-4): 308-317. http://dx.doi. org/10.1016/j.vetpar.2006.02.001. PMid:16516388

Marley CL, Cook R, Barrett J, Keatinge R, Lampkin NH. The effects of birdsfoot trefoil (Lotus corniculatus) and chicory (Cichorium intybus) when compared with perennial ryegrass (Lolium perenne) on ovine gastrointestinal parasite development, survival and migration. Vet Parasitol 2006b; 138(3-4): 280-290. http://dx.doi.org/10.1016/j. vetpar.2006.01.029. PMid:16495015

Ndamukong KJN, Ngone MM. Development and survival of Haemonchus contortus and Trichostrongylus sp. on pasture in Cameroon. Trop Anim Health Prod 1996; 28(3): 193-198. http://dx.doi.org/10.1007/ BF02240933. PMid:8888523

Niezen JH, Waghorn GC, Charleston WA. Establishment and fecundity of Ostertagia circumcincta and Trichostrongylus colubriformis in lambs fed lotus (Lotus pedunculatus) or perennial ryegrass. Vet Parasitol 1998a; 78(1): 13-21. http://dx.doi.org/10.1016/S0304-4017(98)00121-6. PMid:9703616

Niezen JH, Charleston WAG, Hodgson J, Miller CM, Waghorn TS, Robertson HA. Effect of plant species on the larvae of gastrointestinal nematodes which parasitise sheep. Int J Parasitol 1998b; 28(5): 791-803. http://dx.doi.org/10.1016/S0020-7519(98)00019-8. PMid:9650060

Oliveira ALF, Costa C, Rodella RA, Silva BF, Amarante AFT. Effect of plant trichomes on the vertical migration of Haemonchus contortus infective larvae on five tropical forages. Trop Anim Health Prod 2009; 41(5): 775-782. http://dx.doi.org/10.1007/s11250-008-9251-1. PMid:18975119

Rocha RA, Bricarello PA, da Rocha GP, Amarante AFT. Recuperação de larvas de Trichostrongylus colubriformis em diferentes estratos de Brachiaria decumbens e Panicum maximum. Rev Bras Parasitol Vet 2007 16(2): 77-82. PMid:17706008.

Rocha RA, Rocha GP, Bricarello PA, Amarante AFT. Recuperação de larvas infectantes de Trichostrongylus colubriformis em três espécies de gramíneas contaminadas no verão. Rev Bras Parasitol Vet 2008; 17(4): 227-234. PMid:19265583.

Rocha RA, Bricarello PA, Rocha GP, Amarante AF. Recovery of Trichostrongylus colubriformis infective larvae from three grass species contaminated in the autumn. Rev Bras Parasitol Vet 2012; 21(4): 372-378. http://dx.doi.org/10.1590/S1984-29612012000400006. PMid:23295818

Silva BF, Amarante MRV, Kadri SM, Carrijo-Mauad JR, Amarante AFT. Vertical migration of Haemonchus contortus third stage larvae on Brachiaria decumbens grass. Vet Parasitol 2008; 158(1-2): 85-92. http:// dx.doi.org/10.1016/j.vetpar.2008.08.009. PMid:18824304

Skinner WD, Todd KS Jr. Lateral migration of Haemonchus contortus larvae on pasture. Am J Vet Res 1980; 41(3): 395-398. PMid:7369613.

Teixeira FA, Bonomo P, Pires AJV, Silva FF, Fries DD, Hora DS. Produção anual e qualidade de pastagem de Brachiaria decumbens diferida e estratégias de adubação nitrogenada. Acta Sci Anim Sci 2011; 33(3): 241-248. http://dx.doi.org/10.4025/actascianimsci.v33i3.10194. 